\title{
$P-289$ 叒細胞空再発因子の検討
}

\section{北里大学}

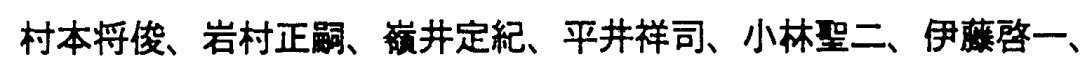

内田僼昭、遗臀忠雄、小柴 硉

（目的）堅細胞癌の再発機序には未だ不明な点が多く一定の見解が得られていない。今回、 督細胞癌術後再発に関わる諸因子を検討したので報告する。

（対象と方法）1971 年から1895年の 25 年間に北里大学病院泌尿器科で経験した 腎細胞癌 275 例を対象とした。根治的堅摘出術を施行し術後診断がstage III 以下のもの 164 例中再発例は 37 例、非再発例は 127 例であった。両群の中から年令、病期が合 致する症例を1：1で無作為に抽出し、統計学的に比較検討した。（結果および考察）転移

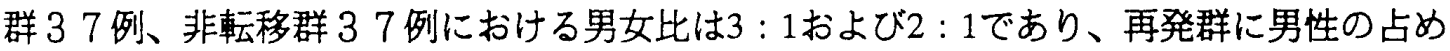
る割合が多かった。両群間に原疾患の左右差は認められず、また術前の監動脈塞栓術施行 の有無、術式として堅への到達経路、原発栄に対する術式、リンパ節郭清の有無による差 も認められなかった。しかし腫場径、悪性度には有意差を認め、非転移群には clear cell subtype が多い傾向にあった。今後、臨床検査データやINF 含めた術後 adjubant 療法の 有無等を加え、多变量解析を行い報告する予定である。

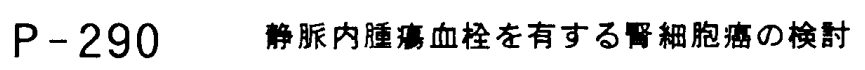 \\ 川崎医科大学 \\ 絹川敬吾, 藤井智浩, 古川洋二, 田中啓幹
}

[目的]海脈内腫演血栓を有する腎細胞癌について臨床的および病理学的検討を行なった。

[対象抢よび方法］1974年1月から1991年1月までの 21 年間に川崎医科大学で手術を施行した腎 細胞癌 117 例のうち, 病理学的に静脈内董瘍血栓を認めた 32 例を対象とした。年踰は，11〜80 歳 (平均 60 葴)，性別は男性 27 例，女性 5 例，患側は右 18 例，左 14 例であった。術式は留部分切除 街 2 例, 単純腎摘除術 5 例, 根治的腎摘除術 26 例, その5 55 例に下大静脈部分切除術, 1 例に人 工血管補填を行なった。病理組織学的所見で，悪性度は $G 1: 2$ 例， $G 2: 21$ 例， $G 3: 9$ 例, 細胞型

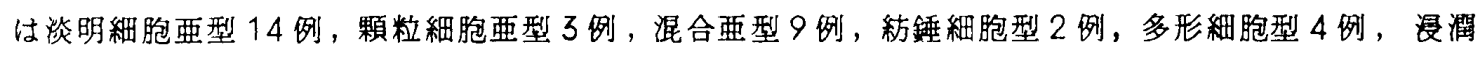
增殖様式は INF- $\alpha 13$ 例，INF- $\beta 14$ 例，INF- $r 5$ 例であった。腫崵血栓の介在部位は增田らの分 類に準じた。

[結果] 腫演血栓介在部位は $\mathrm{pV}_{1 \mathrm{a}} 12$ 例, $\mathrm{pV}_{1 \mathrm{~b}} 10$ 例, $\mathrm{pV}_{2} 10$ 例 (renal type 5 例, infrahepatic type 5例)であった。5 年生存率は, $\mathrm{pV}_{1 \mathrm{a}} \mathrm{MO}: 100 \%$ (観察期間 9〜170月, 中央值: 59 月), $\mathrm{pV}_{1 \mathrm{~b}} \mathrm{MO}: 23.8 \%$ (観察期間 2１36月，中央值：22月）, $\mathrm{pV}_{2} \mathrm{MO}: 50 \%$ (観察期間 7〜 107 月, 中央值 $: 38$ 月) であり，遠隔転移のない $\mathrm{pV}_{2}$ 症例では, 瘇㴻血栓の完全摘出が可能であった 症例において長期生存がみられた。

[考察 $] \mathrm{pV}_{1 \mathrm{~b}} ， \mathrm{pV}_{2}$ 症例の予後は， $\mathrm{pV}_{1 \mathrm{a}}$ に比し悪く予後規定因子の1つと考えられた。しかし, 遠 隔転移のない $\mathrm{pV}_{2}$ 症例では, 糟極的に根治手術を行ならことが大切と思われる。 